\title{
Villous, hypermucinous mucosa in long standing ulcerative colitis shows high frequency of K-ras mutations
}

\author{
S N Andersen, T Løvig, O P F Clausen, A Bakka, O Fausa, T O Rognum
}

\begin{abstract}
Background-K-ras mutation is one of the first genetic alterations in classical colorectal carcinogenesis.

Aims-To investigate the role of K-ras mutations in carcinogenesis, in long standing ulcerative colitis.

Methods-A total of 161 microdissected and 100 DNA samples from 13 patients were analysed for $\mathrm{K}$-ras codons 12 and 13 mutations by means of a combination of enriched polymerase chain reaction amplification and temporal temperature gradient electrophoresis.

Results-K-ras mutations were found in $21 / 161(13 \%)$ microdissected samples in $7 / 13$ large bowels (16 and five in codons 12 and 13 , respectively), and in $10 / 100(10 \%)$ mucosal DNA samples (six and four, respectively). One of four patients with six adenocarcinomas had a $\mathrm{K}$-ras mutation in a carcinoma, as well as one of two patients with large dysplasia associated lesion or mass (DALM). Eight of $13(61 \%)$ areas with villous architecture and large, distended goblet cells, had a K-ras mutation, which was significantly more frequent than in low grade dysplasia (one of $23,4 \%$ ) but did not reach significance versus high grade dysplasia (four of $14,28.5 \%$ ). K-ras mutations were found in one of $20(5 \%)$ flat lesions indefinite for dysplasia, two of 14 $(14 \%)$ in non-villous, hypermucinous mucosa, and in one of 57 flat areas negative for dysplasia.

Conclusion-The highest K-ras mutation frequency was found in villous, hypermucinous mucosa. We suggest that this entity should be investigated further as a potential risk lesion for cancer development. It may represent a pathway directly from non-classical dysplasia to cancer, not previously described.

(Gut 1999;45:686-692)
\end{abstract}

Keywords: K-ras mutations; ulcerative colitis; dysplasia; dysplasia associated lesion or mass

Medical Department A, The National Hospital, University of Oslo, Norway

O Fausa

Correspondence to:

Dr S N Andersen; Institute of Forensic Medicine, The National Hospital, N-0027 Oslo, Norway.

Accepted for publication 2 June 1999

According to the multistep route of genetic alterations in the colorectal adenomacarcinoma sequence, K-ras mutation is one of the first alterations to occur. ${ }^{1}$ The frequency of $\mathrm{K}$-ras mutation in adenomas increases with size, adenoma type, and grade of dysplasia, and different authors report mutations in $40-70 \%$ of adenomas larger than $2 \mathrm{~cm}$, and in $39-58 \%$ of adenomas with high grade dysplasia. ${ }^{2-4}$ In colorectal adenocarcinomas several groups have found the frequency of $\mathrm{K}$-ras mutation to be about $40 \% .^{5-8}$

There is no unanimous agreement concerning the succession of genetic alterations developing in ulcerative colitis - that is, whether the mutations accumulate gradually in parallel to the grade of dysplasia. Carcinomas in ulcerative colitis have many of the same mutations as sporadic colorectal adenocarcinomas, but they have been found in various frequencies in different investigations. Concerning K-ras mutations, some groups have found mutations in carcinomas and dysplasia in ulcerative colitis to be lower than in sporadic adenocarcinoma and adenomas, ${ }^{9-13}$ while others showed K-ras mutation frequency in carcinoma in ulcerative colitis to be about the same as in sporadic adenocarcinoma. $^{8}{ }^{14-16}$

The aim of this study was to relate classical histopathological methods for the grading of dysplasia in ulcerative colitis to a genetic marker of known distribution in other precancerous lesions, for instance, in large bowel adenomas.

\section{Materials and methods}

PATIENTS

Thirteen patients who underwent coloproctectomy consecutively in the period from June 1992 to September 1994 were chosen for these investigations. Ten patients were men and three were women, median age 41 years (29-75 years). They suffered from long standing ulcerative colitis (10-30 years) and were followed up with regular biopsies for evaluation of dysplasia. Nine of the patients were resected because of persisting dysplastic changes, whereas four had developed carcinoma. Three of them had been followed up in other hospitals, dropped out of the surveillance programme for a period of two to three years, and then returned with carcinoma. The fourth patient developed a Dukes's stage A carcinoma between two control visits 12 months apart. Two patients with a dysplasia associated lesion or mass (DALM) ${ }^{17}$ had been followed up in other cities until the lesions were detected.
COLECTOMY SPECIMENS ferent types of epithelial changes, including dysplasia and cancer. All specimens displayed

Abbreviations used in this paper: DALM, dysplasia associated lesion or mass; PCR, polymerase chain reaction; TTGE, temporal temperature gradient electrophoresis.
The proctocolectomy specimens showed dif- 
Table 1 Clinical and pathological data of patients with ulcerative colitis

\begin{tabular}{lllllll}
\hline Patient no & Age $(y)$ & Sex & Duration $(y)$ & Dukes'stage/DALM & Localisation of tumour & $\begin{array}{c}\text { Maximal grade } \\
\text { of dysplasia } \\
\text { except tumour }\end{array}$ \\
\hline 1 & 75 & M & 16 & C, multifocal & Transverse/left & High grade \\
2 & 41 & M & 25 & C & Sigmoid & Low grade \\
3 & 31 & M & 16 & A & Caecum & High grade \\
4 & 35 & F & 23 & D & Transverse & Low grade \\
5 & 40 & M & 26 & Villous DALM, intramucosal & Transverse & Low \\
& & & & & carcinoma & High grade \\
6 & 64 & F & 13 & Tubulovillus DALM, high & Rectum & High grade \\
7 & 41 & M & 11 & & & High grade \\
8 & 39 & M & 16 & & & High grade \\
9 & 41 & M & 24 & & & High grade \\
10 & 46 & M & 30 & & & Low grade \\
11 & 38 & M & 20 & & & Low grade \\
12 & 45 & M & 10 & & & Low grade \\
13 & 29 & F & 15 & & & \\
\hline
\end{tabular}

more or less inactive colitis with little active inflammation. Four patients had adenocarcinomas: one had a Dukes's A carcinoma in the caecum, another a Dukes's C in the sigmoid, a third patient presented a multifocal and mucinous Dukes's C carcinoma with three tumours in the transverse and descending colon, and the fourth had a Dukes's D adenocarcinoma with primary tumour in the transverse colon. One patient had a large DALM (diameter $8 \mathrm{~cm}$ ) with intramucosal carcinoma in the transverse colon, and one patient showed a DALM $(4 \mathrm{~cm})$ with high grade dysplasia in the rectum (table 1 ).

All colectomy specimens were opened longitudinally and rinsed in ice cold phosphate buffered saline (PBS), $\mathrm{pH}$ 7.6, immediately after removal, and thereafter placed in a bucket of PBS which was immersed in ice. Within eight hours tissues from eight or nine segments were removed; neighbouring tissue blocks were either fixed in $96 \%$ ethanol at $4{ }^{\circ} \mathrm{C}^{18}$ or formalin, embedded in paraffin wax or OCT preservative (Miles Inc., Elkhart, Indiana, USA) for freezing. Finally, mucosa samples in close proximity to the tissue blocks were scraped off and prepared as single cell suspensions for subsequent DNA extraction.

HISTOPATHOLOGICAL LESIONS

For each colectomy sample, the histopathological lesions of interest were first identified on routinely stained slides and classified according to Riddell et al. ${ }^{19}$ In addition, two variants with hypermucinous epithelium were defined, one

Table 2 Distribution of K-ras mutations according to histological evaluation and grade of dysplasia in microdissected areas

\begin{tabular}{llll}
\hline $\begin{array}{l}\text { Lesion type } \\
\text { 1. Negative for dysplasia/regeneration }\end{array}$ & $n$ & $\begin{array}{l}\text { K-ras } \\
\text { mutation }(\%)\end{array}$ & $p$ Value \\
& 57 & $1(<2)$ & $\begin{array}{l}0.12^{\mathrm{a}} \\
<0.001^{\mathrm{e}} \\
<0.01^{\mathrm{h}}\end{array}$ \\
& & & $0.02^{\mathrm{j}}$ \\
2. Non-villous, hypermucinous, without dysplasia & 14 & $2(14)$ & $0.03^{\mathrm{b}}$ \\
3. Villous, hypermucinous, indefinite for dysplasia & 13 & $8(61)$ & $0.002^{\mathrm{c}}$ \\
& & & $<0.01^{\mathrm{d}}$ \\
& & & $\mathrm{NS}^{\mathrm{f}}$ \\
$\begin{array}{l}\text { 4. Indefinite for dysplasia, flat mucosa } \\
\text { 5. Low grade dysplasia }\end{array}$ & 20 & $1(5)$ & $0.04^{\mathrm{g}}$ \\
6. High grade dysplasia & 23 & $1(4)$ & \\
7. Carcinoma (six carcinomas in all) & 14 & $4(28.5)$ & \\
\hline
\end{tabular}

Compared with lesion 2 ; ${ }^{\mathrm{b}}$ compared with lesion $3 ;{ }^{\mathrm{c}}$ compared with lesion $4 ;{ }^{\mathrm{d}}$ compared with lesion 5 ; ${ }^{\mathrm{e}}$ compared with lesion 3 ; ${ }^{\mathrm{f}}$ compared with lesion $6{ }^{\mathrm{g}} \mathrm{c}$ compared with lesion $7{ }^{\mathrm{h}}{ }^{\mathrm{h}}$ compared with lesion 6 ; ${ }^{\mathrm{i}}$ compared with lesion 7 .

$\star$ Four sections from the same carcinoma. of them described by Morson et al: villous surface with high number of goblet cells, but without nuclear atypia. ${ }^{20}$ The other variant had abundant goblet cells, no nuclear atypia, but a flat surface. Altogether, 161 mucosal lesions were selected (table 2).

MICRODISSECTION

Parallel sections were cut with the microtome set at $6 \mu \mathrm{m}$, and the slides dried overnight at $37^{\circ} \mathrm{C}$. Corresponding areas of interest were delineated and microdissected under a Leica dissection stereomicroscope after rapid staining with haematoxylin and eosin. Thereafter the tissue was scraped off the slide (the sections were covered by $25 \mu \mathrm{l}$ Tris buffer, $0.05 \mathrm{~mol}$ ), with the tip of a sealed glass pipette and then sucked into a microcapillary. Figures $1 \mathrm{~A}$ and B show the same slide before and after microdissection. Tissue samples were then put into Eppendorf tubes and incubated with proteinase $\mathrm{K}$ at $37^{\circ} \mathrm{C}$ overnight. Proteinase $\mathrm{K}$ activity was inactivated by heating to $95^{\circ} \mathrm{C}$ for $10 \mathrm{~min}$ utes, and the resulting solutions were used directly as templates for K-ras analyses.

DNA EXTRACTION

For DNA extraction from fresh mucosa in close vicinity to the tissue blocks, standard methods were used: after incubation with pro-

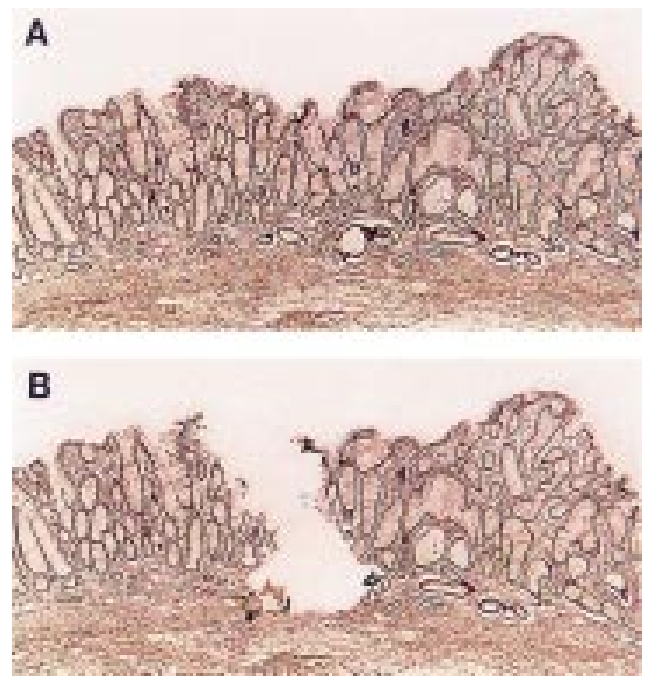

Figure 1 Section from large bowel mucosa of patient 2, rich in goblet cells, but without dysplasia, $(A)$ before and (B) after microdissection. 


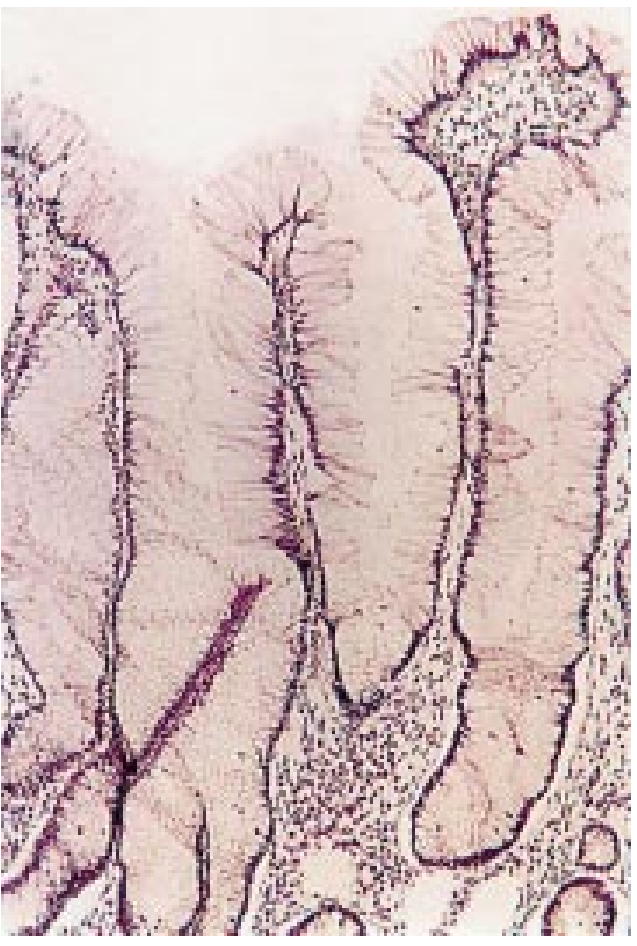

Figure 2 Mucosal specimen from patient 11, with villous growth pattern and elongated, distended goblet cells without cytological atypia. This area was K-ras mutation positive.

teinase $\mathrm{K}$ at $37^{\circ} \mathrm{C}$ overnight the mucosa was extracted twice in phenol and twice in chloroform, followed by ethanol precipitation.

K-ras MUTATION ANALYSIS

K-ras mutations in codons 12 and 13 were identified in DNA from each of the microdissected areas, as well as in mucosa extracted from neighbouring areas, by means of a modification of the "enriched PCR method"? combined with temporal temperature gradient electrophoresis (TTGE) ${ }^{21}$

Briefly, the initial PCR reaction (A) was performed in $25 \mu$ l of PCR amplification buffer $(50 \mathrm{mmol} / 1$ potassium chloride, $10 \mathrm{mmol} / 1$ Tris $\mathrm{HCl}, 1.5 \mathrm{mmol} / 1$ magnesium chloride), with either $1 \mu \mathrm{l}$ of template from microdissection or $50 \mathrm{ng}$ of extracted DNA, $25 \mu \mathrm{mol}$ of each deoxynucleoside triphosphate, $0.28 \mu \mathrm{g}$ TaqStart Antibody (Clontec, Palo Alto, California, USA), 1.25 U of Taq DNA polymerase (Promega, Madison, Wisconsin, USA), and $0.04 \mu \mathrm{mol}$ and $0.2 \mu \mathrm{mol}$ of the oligonucleotide

Table 3 Survey of K-ras mutation positive lesions in each of the 13 patients

\begin{tabular}{lclcc}
\hline Patient no & $\begin{array}{l}\text { Microdissected } \\
\text { lesions }\end{array}$ & $\begin{array}{l}\text { K-ras mutation } \\
\text { positive (\%) }\end{array}$ & $\begin{array}{l}\text { Mucosa } \\
\text { specimens }\end{array}$ & $\begin{array}{l}\text { K-ras mutation } \\
\text { positive (\%) }\end{array}$ \\
\hline 1 & 18 & 0 & 8 & 0 \\
2 & 15 & $5(33)$ & 8 & $2(25)$ \\
3 & 19 & $2(11)$ & 8 & $1(12.5)$ \\
4 & 8 & 0 & 4 & 0 \\
5 & 13 & 0 & 8 & 0 \\
6 & 15 & $3(20)$ & 8 & $1(12.5)$ \\
7 & 11 & 0 & 8 & 0 \\
8 & 13 & $2(20)$ & 9 & $2(22)$ \\
9 & 10 & $2(22)$ & 8 & $1(12.5)$ \\
10 & 9 & $6(37.5)$ & 7 & $1(14.5)$ \\
11 & 16 & 0 & 9 & $1(14.5)$ \\
12 & 6 & 0 & 7 & 0 \\
13 & 8 & $21(13)$ & 100 & $10(10)$ \\
Total & 161 & & &
\end{tabular}

primers (Genosys Biotechnology, Houston, Texas, USA) $5 \mathrm{~K} 1$ and $3 \mathrm{~K} 1$ respectively: 5'-ACTGAATATAAACTTGTGGTCCATG GAGCT-3' and 5'-TTATCTGTATCAAAGAA TGGTCCTGCACCA-3'. These primers give a PCR product of $170 \mathrm{bp}$. The $5 \mathrm{~K} 1$ primer was designed (modified, mismatching bases are underlined) to induce two restriction sites in the wild type (WT) amplification product $(\mathrm{N}=$ any base): 5'-CCANNNNNNTGG-3' which is recognised by endonuclease BstXI, and involves WT codon 12. 5'-CCANNNNNNNNNTGG $-3^{\prime}$ is recognised by endonuclease $X c m \mathrm{I}$, and involves WT codon 13.

The amplification was performed in a GeneAmp PCR System 9600 (Perkin-Elmer, Foster City, California, USA). The reaction was run for 20 cycles consisting of 30 seconds denaturation at $94^{\circ} \mathrm{C}$, one minute annealing at $50^{\circ} \mathrm{C}$, and two minutes elongation at $72^{\circ} \mathrm{C}$. After the last cycle the tubes were kept at the elongation temperature for 10 minutes. A $5 \mu \mathrm{l}$ aliquot of the amplification product was incubated with either $10 \mathrm{U}$ of BstXI or $2 \mathrm{U}$ of $X \mathrm{cmI}$. Digestion was performed as recommended by the supplier of both the endonucleases (New England Biolabs, Beverly, Massachusetts, USA), in a volume of 20 $\mu 1$. A $5 \mu$ aliquot of the digested amplification product was used directly as a template in an amplification reaction (PCR B) of $25 \mu \mathrm{l}$. This time the following primers were used: 5'ATGACTGAATATAAACTTGTG and 5'GCCCCGCGCCCGTCCCGCCGCCCCC GCCCG CTC TAT TGT TGG ATC ATA in final concentrations of 0.32 and $0.16 \mu \mathrm{mol}$ each, together with PCR amplification buffer, $100 \mu \mathrm{mol}$ of each deoxynucleoside triphosphate, and $1 \mathrm{U}$ of $T a q$ polymerase.

The reverse GC clamped primer is nested to $3^{\prime} \mathrm{K} 1$, and these two primers give a PCR product of $111 \mathrm{bp}$.

After the first annealing step of two minutes at $95^{\circ} \mathrm{C}$, the reaction was run for 35 cycles consisting of 30 seconds denaturation at $95^{\circ} \mathrm{C}$, 30 seconds annealing at $58^{\circ} \mathrm{C}$, and 30 seconds elongation at $72^{\circ} \mathrm{C}$. After the last cycle the tubes were kept at the elongation temperature for five minutes. The PCR amplification products were verified on $2 \%$ agarose gel containing ethidium bromide, and analysed in ultraviolet light, prior to being subjected to temporal temperature gradient electrophoresis (TTGE). ${ }^{21}$

TTGE ANALYSIS

The TTGE analyses were performed with the DCode system (Bio-Rad, Hercules, California, USA), using $16 \times 16 \mathrm{~cm}$ glass plates, with gel containing $10 \%$ acrylamide/bis with $6 \mathrm{~mol} / \mathrm{l}$ urea in $1.25 \times$ TAE buffer $(50 \mathrm{mmol} / 1$ Tris, 25 $\mathrm{mmol} / 1$ acetic acid, $1.25 \mathrm{mmol} / 1$ EDTA), according to the manufacturer's recommendations. The PCR B products were electrophoresed at $130 \mathrm{~V}$ for five hours with a temperature range of $52-62^{\circ} \mathrm{C}$. The gel was then stained in SYBR Green I (Molecular Probes Inc., Eugene, Oregon, USA) and photographed using an ultraviolet transilluminator at $300 \mathrm{~nm}$. 
Table 4 Distribution and type of 21 K-ras mutations in DNA from microdissected areas

\begin{tabular}{|c|c|c|}
\hline Type of lesion & Codon 12 & Codon 13 \\
\hline \multicolumn{3}{|l|}{ Patient 2} \\
\hline Carcinoma, 4 areas & & $\mathrm{GGC} \rightarrow \mathrm{GAC} \times 4^{\star}$ \\
\hline Non-villous, hypermucinous, without dysplasia & $\mathrm{GGT} \rightarrow \mathrm{TGT}$ & \\
\hline \multicolumn{3}{|l|}{$\begin{array}{l}\text { Patient } 3 \\
\end{array}$} \\
\hline \multicolumn{3}{|l|}{ Carcinoma K-ras mutation negative } \\
\hline High grade dysplasia near carcinoma & $\mathrm{GGT} \rightarrow \mathrm{GTT}$ & \\
\hline Villous, hypermucinous, indefinite dysplasia & & $\mathrm{GGC} \rightarrow \mathrm{GAC}$ \\
\hline \multicolumn{3}{|l|}{$\begin{array}{l}\text { Patient } 6 \\
\text { Palla }\end{array}$} \\
\hline Tubulovillous DALM, high grade & GGT $\rightarrow$ GAT & \\
\hline High grade dysplasia near DALM & $\mathrm{GGT} \rightarrow \mathrm{GCT}$ & \\
\hline High grade dysplasia near DALM & $\mathrm{GGT} \rightarrow \mathrm{GCT}$ & \\
\hline \multicolumn{3}{|l|}{$\begin{array}{l}\text { Patient } 7 \\
\text { P }\end{array}$} \\
\hline Regeneration, no dysplasia & $\mathrm{GGT} \rightarrow \mathrm{GAT}$ & \\
\hline \multicolumn{3}{|l|}{ Patient 9} \\
\hline Villous, hypermucinous, indefinite dysplasia & $\mathrm{GGT} \rightarrow \mathrm{AGT}$ & \\
\hline Villous, hypermucinous, indefinite dysplasia & $\mathrm{GGT} \rightarrow \mathrm{AGT}$ & \\
\hline \multicolumn{3}{|l|}{ Patient 10} \\
\hline Low grade dysplasia & GGT $\rightarrow$ GAT & \\
\hline Villous, hypermucinous, indefinite dysplasia & GGT $\rightarrow$ GAT & \\
\hline \multicolumn{3}{|l|}{ Patient 11} \\
\hline Non-villous, hypermucinous, without dysplasia & $\mathrm{GGT} \rightarrow \mathrm{GAT}$ & \\
\hline Villous, hypermucinous, indefinite dysplasia & $\mathrm{GGT} \rightarrow \mathrm{AGT}$ & \\
\hline Villous, hypermucinous, indefinite dysplasia & $\mathrm{GGT} \rightarrow \mathrm{AGT}$ & \\
\hline Villous, hypermucinous, indefinite dysplasia & $\mathrm{GGT} \rightarrow \mathrm{AGT}$ & \\
\hline Villous, hypermucinous, indefinite dysplasia & $\mathrm{GGT} \rightarrow \mathrm{AGT}$ & \\
\hline Flat lesion, indefinite dysplasia & $\mathrm{GGT} \rightarrow \mathrm{GAT}$ & \\
\hline
\end{tabular}

^Identical mutation at different levels. DALM, dysplasia associated lesion or mass.

DNA SEQUENCING

All mutation positive samples from the TTGE analysis were sequenced in order to identify the exact base substitution. PCR products were purified using the Qiaquick PCR purification kit (Qiagen, Hilden, Germany) and sequenced using dye primer cycle sequencing and AmpliTaq polymerase FS on an Applied Biosystems 377 DNA sequencer.

CONTROLS

DNA from colon carcinoma cell lines SW480 (Clontech, Palo Alto, California, USA) and HCT116 (American Type Culture Collection, ATCC, Rockville, Maryland, USA) with known K-ras mutations at codon 12 (GTT) and codon 13 (GAC) respectively, were used as positive controls in each of the parallel procedures. Negative controls, without DNA, were run as controls for contamination.

STATISTICAL ANALYSIS

Associations between different variables were examined using the $\chi^{2}$ method with Yates's correction; $p$ values less than 0.05 were considered statistically significant.

\section{Results}

HISTOPATHOLOGY

Each of the 161 microdissected areas was diagnosed by one experienced pathologist (SNA). To check for interobserver reproducibility, 59 adjacent sections were blindly and independently evaluated for different grades of dysplasia according to standard criteria for comparison, ${ }^{19}$ by two histopathologists (SNA and OPFC) with a $\kappa$ value of 0.64 , which means substantial agreement. ${ }^{22}$ The remainder of the slides were afterwards agreed on by OPFC. Intraobserver agreement (SNA) after three months was "almost perfect" $(\kappa=0.82)$.

One third of the microdissected areas $(n=57)$ consisted of carcinoma or high or low grade dysplasia, while 20 showed flat mucosa, indefinite for dysplasia. Thirteen areas from six large bowels contained a villous growth pattern with hypermucinous, distended goblet cells (fig 2), and 14 were non-villous, hypermucinous, and without dysplasia. Table 2 shows the different types of lesions.

\section{$\mathrm{K}$-ras MUTATIONS}

Altogether $261 \mathrm{~K}$-ras analyses were performed on tissue from 13 colectomy specimens: 161 from microdissected tissue and 100 from DNA extracted from nearby mucosa. K-ras mutations were found in $21(13 \%)$ and $10(10 \%)$ of these, respectively. Table 3 shows a survey of microdissected lesions and mucosa specimens in each of the patients, and the number of K-ras mutation positive lesions. Six of the 13 large bowels did not show any K-ras mutation by analysis of microdissected lesions, while DNA from mucosa specimens was K-ras mutation negative in five bowels.

Twenty one of the 161 microdissected areas $(13 \%)$ were K-ras mutation positive, 16 in codon 12 and five in codon 13 . Only one of the four patients $(25 \%)$ with a total of six carcinomas had a tumour containing a K-ras mutation. Four of the 20 carcinoma specimens analysed were from this tumour, taken at different levels of infiltration (table 4), and showing identical mutation. Four of $14(28.5 \%)$ high grade lesions were K-ras mutation positive, while only one of $23(4 \%)$ low grade lesions and one of 20 $(5 \%)$ lesions indefinite for dysplasia in flat mucosa were positive (table 2).

Eight of $13 \mathrm{~K}$-ras mutation positive lesions $(61 \%)$ were found in mucosa with villous growth pattern with "hypermucinous" epithelium, very rich in large, distended goblet cells, having nuclei without definite cytological atypia. These had previously been defined as "indefinite for dysplasia", as delineated by Morson et al. ${ }^{20}$ The frequency of K-ras mutations in this entity was significantly higher than in low grade dysplasia ( $p<0.001$, table 2$)$, but did not reach significance versus high grade dysplasia. The mutation frequency in villous, hypermucinous mucosa was also significantly higher than compared with flat mucosa, indefinite for dysplasia (one of 20, p=0.002) and areas negative for dysplasia, with regenerating or atrophic mucosa (one of $57, \mathrm{p}=0.001$ ). Two of $14(14 \%)$ flat, hypermucinous lesions

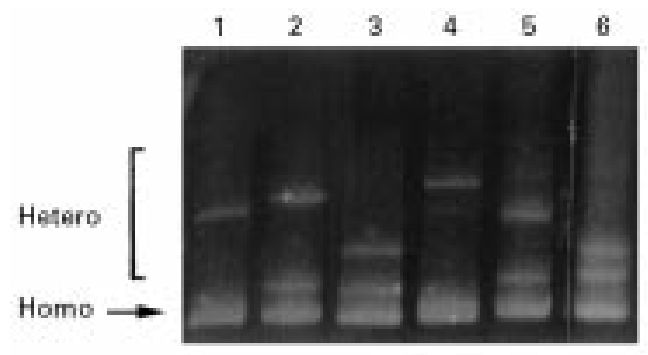

Figure 3 TTGE gel showing migration patterns of K-ras exon 1 fragments. All lanes show different migration patterns at the upper bands (heteroduplex bands), indicating different K-ras mutations. The lower band is the homoduplex band. Lanes 1-5 show codon 12 mutations:

(1) GTT (valine); (2) TGT (cysteine); (3) GAT (aspartate); (4) GCT (alanine); and (5) AGT (serine). Lane 6 shows a codon 13 GAC mutation (aspartate). 
A
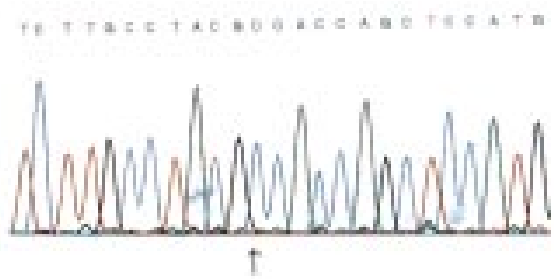

WT

OCT OOT GOC GTA

Aln Gly Gly Val

B
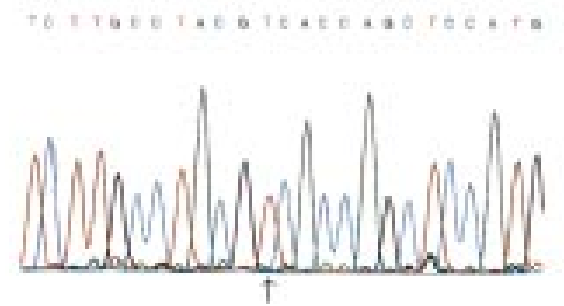

Murant

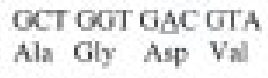

Figure 4 (A) Automated sequence analysis of K-ras, showing wild type sequence GGT in codon 12. This is an inverse analysis, and should be read from right to left. (B). $K$-ras mutation in the second base in codon 12, giving the sequence GAT (aspartate) instead of GGT (glycine).

without dysplasia were $\mathrm{K}$-ras mutation positive $(\mathrm{p}=0.03)$. Figure 2 shows one of the K-ras positive lesions in patient 11 .

Table 4 shows the distribution and type of $\mathrm{K}$-ras mutations in DNA from microdissected areas. Among the eight villous, hypermucinous lesions, four were from patient 11 and showed an identical mutation (12 AGT-serine), despite considerable distance (several $\mathrm{cm}$ ) between each of them. The last four were from three different patients, two from patient 9 (with the same 12 AGT mutation), and the two last (patients 10 and 3) showing an aspartate mutation in codons 12 (GAT) and 13 (GAC), respectively.

Among the two patients with DALM, one was $\mathrm{K}$-ras mutation negative (patient 5), and the other K-ras positive (patient 6), shown both in DNA from microdissection and mucosal "slicing". Figure 3 illustrates gels with mutated bands from K-ras investigations, while fig 4 shows DNA sequence analysis of wild type (A) and mutated (B) K-ras.

\section{Discussion}

The most intriguing result of this investigation was the high proportion of mucosal lesions with villous, hypermucinous appearance, without cytological dysplasia, which were K-ras mutation positive. As carcinomas may develop in ulcerative colitis without concomitant signs of classical dysplasia (Fenoglio-Preiser, personal communication), this new entity should be studied further with regard to association with malignant development. The percentages of $\mathrm{K}$-ras mutation positive carcinomas, and high and low grade lesions were lower than in corresponding lesions related to sporadic colorectal carcinogenesis, and were in agreement with previous findings. ${ }^{9-13} 15$

At least five groups have investigated $\mathrm{K}$-ras mutations in normal and regenerating mucosa and in mucosa indefinite for dysplasia (table 5). ${ }^{910121416}$ Only two of them found K-ras mutations in "normal" mucosa and in lesions indefinite for dysplasia, including so called "villous regeneration" and "serrated lesions". ${ }^{12} 16$ These had no resemblance to hyperplastic polyps. We were particularly interested in the villous lesions with large, distended goblet cells, without cytological atypia, which we have seen in some patients with long standing ulcerative colitis. These lesions were characterised as a separate entity. As the clinical significance with respect to malignant potential of this growth pattern has not yet been determined, Morson $e t$ al recommend that this entity should be categorised as "indefinite for dysplasia" ${ }^{20}$ Riddell et al did not include such lesions in their classical paper about criteria for the classification of dysplasia in inflammatory bowel disease. ${ }^{19}$

In 1987 Lee described villous regeneration in three patients among 92 cases of ulcerative colitis. ${ }^{23}$ In these cases the finger like formations were covered by cuboidal or columnar epithelium with variable degree of maturation towards the lumen, and with enlarged, vesicular nuclei with striking nucleoli. Mucin was absent, although a variable number of goblet cells were present. None of our patients showed this type of mucosa. However, four of our patients (patients 3,9, 10, and 11) showed variable degrees of villous regeneration, often with large, distended goblet cells (fig 2).

In a recent study only 11 of 278 samples (4\%) from seven ulcerative colitis colectomy specimens showed K-ras mutations, among them two of five carcinomas. ${ }^{24}$ The percentages both in dysplastic and non-dysplastic lesions

Table 5 Frequency of $K$-ras mutations in different lesions in long standing ulcerative colitis (UC)

\begin{tabular}{|c|c|c|c|c|c|c|c|c|}
\hline \multirow[b]{2}{*}{ Authors } & \multirow{2}{*}{$\begin{array}{l}\text { Carcinoma } \\
\text { in UC }\end{array}$} & \multicolumn{3}{|l|}{ Dysplasia } & \multirow{2}{*}{$\begin{array}{l}\text { Indefinite for } \\
\text { dysplasia }\end{array}$} & \multirow{2}{*}{$\begin{array}{l}\text { Villous } \\
\text { regeneration }\end{array}$} & & \multirow{2}{*}{$\begin{array}{l}\text { Normal + } \\
\text { active colitis }\end{array}$} \\
\hline & & High grade & & Low grade & & & & \\
\hline Burmer et al ${ }^{9}$ & $1 / 12(8)$ & $0 / 8$ & & $0 / 1$ & $0 / 3$ & & & $0 / 1$ \\
\hline Melzer et $a l^{10}$ & $1 / 4(25)$ & $2 / 6(33)$ & & $0 / 6$ & $0 / 5$ & & & \\
\hline Bell et $a l^{11}$ & $8 / 33(24)$ & & $0 / 8$ & & & & $0 / 5$ & \\
\hline Chaubert et al ${ }^{12}$ & $2 / 9(22)$ & & $5 / 9(55)$ & & & $1 / 6(16)$ & & 2/7 (29) \\
\hline Tsuda et $a l^{13}$ & $1 / 13(8)$ & & $0 / 12$ & & & & & \\
\hline Chen $e t a l^{14}$ & $2 / 3(67)$ & $4 / 8(50)$ & & & $0 / 8$ & & & $0 / 2$ \\
\hline Kern et $a l^{15 \star}$ & $3 / 7(43)$ & $1 / 2(50)$ & & $1 / 3(33)$ & & & & \\
\hline Redston et $a l^{16 \star}$ & $3 / 7(43)$ & $4 / 8(50)$ & & $1 / 7(14)$ & $5 / 14(36)$ & & & $0 / 17$ \\
\hline
\end{tabular}

Percentages are given in parentheses.

^Included two patients with long standing Crohn's disease. 
were about $3 \%$, but the authors have not described the types of non-dysplastic lesions.

Both Chaubert et $a l^{12}$ and Redston et $a l^{16}$ found K-ras mutations in epithelium indefinite for dysplasia or showing regenerative changes. Among lesions indefinite for dysplasia were some borderline lesions of uncertain clinical significance, such as hypermucinous epithelium, serrated epithelium, and epithelium with incomplete maturation. In our study we examined 14 flat lesions with hypermucinous epithelium, and found K-ras mutations in two $(14 \%)$, in patients 2 and 11 (table 4 ). These were situated several $\mathrm{cm}$ apart from the other mutated areas in these patients. None of the former authors' lesions were identical to what we call "villous, hypermucinous lesion with distended goblet cells". Two of our patients (table 4; patients 11 and 9) had two and four areas, respectively, with the same GGT to AGT $\mathrm{K}$-ras mutation, coding for serine, whereas the two last lesions in one patient each had different mutations.

It has been suggested that carcinomas in ulcerative colitis might follow an alternative genetic pathway for tumour progression, as relatively few dysplasias and carcinomas contain K-ras mutations. ${ }^{10-13}$ Benhattar and Saraga $^{25}$ have compiled the results of five reports, ${ }^{10-121415}$ and conclude that K-ras mutation plays an important role in ulcerative colitis associated carcinomas, although the prevalence is slightly lower than in sporadic carcinoma $(30 \%$ versus $40 \%)$. Interestingly, a high frequency of $\mathrm{K}$-ras mutation is found in aberrant crypt foci (ACF), a lesion claimed to be a precursor of both hyperplastic polyps and adenomas. ${ }^{26}$ The same authors claim that K-ras mutations are frequent also in hyperplastic polyps, a type of lesion said to have low malignant potential. ${ }^{27}$ However, we could not find $\mathrm{K}$-ras mutations in any of the 15 hyperplastic polyps which we have examined previously, despite using a more sensitive "enriched PCR method" detecting one mutated K-ras codon 12 or 13 allele in the presence of $10^{4}-10^{5}$ copies of the wild type allele. ${ }^{4}$ The discrepancy may be due to the possibility that only a small fraction of hyperplastic lesions are really neoplastic, and serve as precursor of a subset of colorectal cancers. ${ }^{28}$ One possible explanation could be that ras mutations may have little neoplastic potential in the absence of other mutations, such as $A P C$ and $\mathrm{p} 53 .{ }^{29}$ None of the hypermucinous lesions in the present paper did resemble hyperplastic polyps, but this theory may concern them as well. Therefore, $A P C$ and p53 mutations will soon be investigated.

The materials and methods chosen are important. In our study of microdissected lesions, the tissue used was fixed in ethanol which is a good preservative of nucleic acids. ${ }^{30}$ Our analysis is based on an "enriched PCR method", combined with TTGE and automated sequencing, and the sensitivity of the TTGE method has been estimated to detect a mutation down to about $1 \%$ of the cells. ${ }^{21}$

The frequency of K-ras mutations in DNA extracted from "sliced" mucosa close to the tissue blocks was about the same as by micro- dissection (10\% versus 13\%), but did not always show the same result. This might be explained by the fact that although neighbouring tissue was used, often less than $4 \mathrm{~mm}$ apart, the K-ras mutation positive clones may be of even smaller size.

Villous, hypermucinous lesions, previously included among mucosal lesions indefinite for dysplasia, had twice the K-ras mutation frequency compared with high grade dysplasia. We suggest that this new entity should be investigated further as a potential risk lesion for cancer development. Mucinous carcinomas are relatively frequent in patients with ulcerative colitis. ${ }^{31}$ Perhaps villous, hypermucinous lesions may represent a pathway directly from non-classical dysplasia to cancer, not previously described.

The authors are grateful to The Norwegian Cancer Society for financial support. They also wish to thank the staff at the Surgical Department B, the National Hospital, who provided the colectomy specimens, and Iris Arnesen and Ann Kristin Stave for technical help.

1 Fearon ER, Vogelstein B. A genetic model for colorectal tumorigenesis. Cell 1990;61:759-67.

2 Vogelstein B, Fearon ER, Hamilton SR, et al. Genetic alterations during colorectal-tumor development. $N$ Engl f Med 1988;319:525-32.

3 McLellan EA, Owen RA, Stepniewska KA, et al. High frequency of K-ras mutations in sporadic colorectal adenomas. Gut 1993;34:392-6.

4 Norheim Andersen S, Breivik J, Løvig T, et al. K-ras mutations and HLA-DR expression in large bowel adenomas. $\mathrm{Br}$ f Cancer 1996;74:99-108.

5 Bos JL, Fearon ER, Hamilton SR, et al. Prevalence of ras gene mutations in human colorectal cancers. Nature 1987; 327:293-7.

6 Benhattar J, Losi L, Chaubert P, et al. Prognostic ignificance of K-ras mutations in colorectal carcinoma. Gastroenterology 1993;104:1044-8.

7 Norheim Andersen S, Løvig T, Breivik J, et al. K-ras mutations and prognosis in large bowel carcinomas. Scand $\mathcal{F}$ Gastroenterol 1997;32:62-9.

8 Andreyev HJN, Norman AR, Cunningham D, et al. Kirsten ras mutations in patients with colorectal cancer: the multicenter "RASCAL" study. F Natl Cancer Inst 1998;90:67584.

9 Burmer GC, Levine DS, Kulander BG, et al. C-Ki-ras mutations in chronic ulcerative colitis and sporadic colon carcinoma. Gastroenterology 1990;99:416-20.

10 Meltzer SJ, Mane SM, Wood PK, et al. Activation of c-Ki-ras in human gastro-intestinal dysplasias determined by direct sequencing of polymerase chain reaction products. Cancer Res 1990;50:3627-30.

11 Bell SM, Kelly SA, Hoyle JA, et al. c-Ki-ras gene mutations in dysplasia and carcinomas complicationg ulcerative colitis. Br 7 Cancer 1991;64:174-8.

12 Chaubert P, Benhattar J, Saraga E, et al. K-ras mutations and $\mathrm{p} 53$ alterations in neoplastic and nonneoplastic lesions associated with longstanding ulcerative colitis. Am $\mathcal{F}$ Pathol 1994;144:767-75.

13 Tsuda T, Mochizuki M, Wasaka H. Detection of c-ras gene mutation and expression of $\mathrm{p} 21$ protein in dysplasias and carcinomas complicating ulcerative colitis. $f$ Gastroenterol 1995;30(suppl VIII):30-2.

14 Chen J, Compton C, Cheng E, et al. c-Ki-ras mutations in dysplastic fields and cancers in ulcerative colitis. Gastroenterology 1992;102:1983-7.

15 Kern SE, Redston M, Seymour AB, et al. Molecular genetic profiles of colitis-associated neoplasms. Gastroenterology

16 Redston MS, Papadopoulos N, Caldas C, et al. Common occurrence of APC and K-ras gene mutations in the specoccurrence of APC and K-ras gene mutations in the spec-
trum of colitis-associated neoplasias. Gastroenterology 1995; 108:383-92.

17 Torres C, Antonioli D, Odze RD. Polypoid dysplasia and adenomas in inflammatory bowel disease. Am F Surg Pathol 1998;22:275-84

18 Sainte-Marie G. A paraffin embedding technique for studies employing immuno-fluorescence. $\mathcal{F}$ Histochem Cytochem 1962;10:250-6

19 Riddell RH, Goldman H, Ransohoff DF, et al. Dysplasia in inflammatory bowel disease: standardized classification with provisional clinical applications. Hum Pathol 1983;14: with provis $931-68$.

20 Morson BC, Jass JR, Sobin LH. Precancerous lesions of the gastrointestinal tract. A histological classification, Volume 1. Londrointestimal tract. A Ailière Tindall, 1985:139.

21 Bjørheim J, Lystad S, Lindblom A, et al. Mutation analyses of KRAS exon 1 comparing three different techniques: temporal temperature gradient electrophoresis, constant 
denaturant capillary electrophoresis and allele specific polymerase chain reaction. Mutation Res 1998;403:103-12. 22 Landis JR, Koch GG. The measurement of observer agre ment for categorical data. Biometrics 1977;33:159-74.

23 Lee RG. Villous regeneration in ulcerative colitis. Arch Pathol Lab Med 1987;111:276-8.

24 Holzmann K, Klump B, Borchard F, et al. Comparative analysis of histology, DNA content, p53 and Ki-ras mutations in colectomy specimens with long-standing ulcerative colitis. Int $\mathcal{F}$ Cancer 1998;76:1-6.

25 Benhattar J, Saraga E. Molecular genetics of dysplasia in ulcerative colitis. Eur f Cancer 1995;31A:1171-3.

26 Otori K, Sugiyama K, Hasebe T, et al. Emergence of adenomatous aberrant crypt foci (ACF) from hyperplastic ACF with concomitant increase in cell proliferation. Cancer Res 1995;55:4743-6.
27 Otori K, Oda Y, Suguiyama K, et al. High frequency of K-ras mutations in human colorectal hyperplastic polyps. Gut 1997;40:660-3

28 Iino H, Jass JR, Simms LA, et al. DNA microsatellite instability in hyperplastic polyps, serrated adenomas, and mixed polyps: a mild mutator pathway for colorectal cancer? $\mathcal{7}$ Clin Pathol 1999;52:5-9.

29 Williams GT Metaplastic (hyperplastic) polyps of the large bowel: benign neoplasms after all? Gut 1997;40:691-2.

30 Greer CE, Lund JK, Manos MM. PCR amplification from paraffin-embedded tissues: recommendations on fixatives for long-term storage and prospective studies. PCR Methods Appl 1991;1:46-50.

31 Symonds DA, Vickery AL. Mucinous carcinoma of the colon and rectum. Cancer 1976;37:1891-900. 